\title{
Dual-Mandate of Persons Who Serve as MPs and Mayors at the Same Time
}

\author{
SAŠA ZAGORC
}

\begin{abstract}
The incompatibility of the function at the state and local levels is defined to prevent exercising a dual mandate and other forms of conflict of interest to secure self-government in local communities. The discussed positions of dual- or even triple-mandate officials are neither unconstitutional nor unlawful in themselves, yet they relate to the incompatibility of interest roles these dual-mandate or triple-mandate officials simultaneously play. The inability of the National Assembly to regulate the issue of the incompatibility of the function in accordance with the basic principles in the state (balance of powers, local self-government autonomy, representative democracy) leads us to the conviction that, for the time being, the parliamentary lobby power is too great, whereas the political culture of the public is too weak to prevent the further steps of the legislator. An important aspect of the incompatibility of the function lies in the fact that individuals should be aware that performing the multiple functions, obtained in elections, is not a privilege, but it is a commitment and duty to perform the functions well and with dedication. The paradox is that an individual who is aware of this does not need any rules on the incompatibility of the function at all.
\end{abstract}

KEY WORDS: $\bullet$ incompatibility of the function $\bullet$ mandate $\bullet$ National Assembly Members $\bullet$ mayor $\bullet$ deputy mayor $\bullet$ local self-government $\bullet$ separation of powers $\bullet$ Slovenia

CORRESPONDENCE ADDRESS: Dr Saša Zagorc, University of Ljubljana, Faculty of Law, Poljanski nasip 2, SI-2000 Ljubljana, Slovenia, e-mail: sasa.zagorc@pf.uni-lj.si. 


\section{Introduction}

The purpose of this paper is to deal with the dual-mandate problem, or in other words, to analyse the function of the National Assembly member and the function of the mayor performed by one person at the same time. In this paper, I shall try to show why the current Slovene parliamentary and mayor's mandate regulation permits unequal treatment of the local self-government units, and what options there are to change the legislation in the direction of providing better quality of the parliamentary and mayor's work. The dual mandate issue in the Slovene constitutional order is actually even more important than it seems at a glance because the number of Assembly members who are also mayors is above average for a relatively small parliament. The public opinion on this issue is surprising. In principle, the voters are against the dual mandate Members (they are MPs and mayors). However, solely for utilitaristic reasons, they often support the candidate who already performs one of the mentioned functions (Foucault, 2006: 292-297). Furthermore, the chances of such a candidate to be elected are, according to the experience in France in 1997, greater than of the rest of the candidates (Foucault, 2006: 306-311). Although it does not seem appropriate to completely transfer the above-mentioned findings to our country, because the electoral systems and other relevant factors at the state and local levels differ in both countries, the research nevertheless confirms that it is about a multi-layer issue that can be ultimately resolved only through the electoral body that puts strong and persistent pressure on the legislator to abolish the dual mandate (referring to MPs who are also mayors).

\section{The Importance of the Incompatibility of the Function at the State and Local Levels}

The local self-government system requires, inter alia, the regulation of relationships with the national authority. This also applies to the option of performing several functions at both levels of authority. The incompatibility of the function at the state and local levels is defined to prevent exercising a dual mandate and other forms of conflict of interest to secure local community selfgovernment. It is a characteristic of the incompatibility of the simultaneous performance of the functions at the state and local self-government level that no complete interruption of the personal activity of the officials at the state and local levels can be dictated because this would lead to the establishment of two independent systems. The satisfaction of the locally defined needs is the basic guiding principle of the functions in local communities, whereas at the state level, broader social and political trends are followed in accordance with the will of the voters in the state elections. It is a characteristic of the incompatibility of the function at the state and local levels that its objective is primarily to prevent the conflict of interest and not so much to consistently observe the separation of powers between the state and local communities. The initial principle relating to the incompatibility of the function at various levels of authority is that the conflict 
of interest is not eliminated only because the two functions are performed at various levels of authority. ${ }^{1}$ But on the other hand, it would be exaggerated to maintain that automatic prohibition of simultaneous performance of functions should be done at various territorial levels of authority. The German theory expressly emphasizes that in the case of the absence of the rules on the incompatibility of the function, only those forms of conflict of interest that refer to the relationships merely between the state bodies and, under no circumstances, the incompatibility of the function at various territorial and organisational levels of authority result from the principle of the separation of powers (Achterberg, Schulte 2000: 1244). Due to the similarity to the German concept of the local selfgovernment, this position can be accepted also in Slovenia.

\section{Assembly Member Function and the Governmental Functions at the Local Level}

The relationship between the state-level bodies and the bodies within the framework of the local self-government represents one of the most burning issues relating to the government organisation. We wonder to what extent both government regulation levels should be distinguished by functional, organisational and personal aspects. To a large extent, answers are influenced by the positions of the constitution-giver and legislator: in what extent and to what degree of independence the local self-government will be implemented in the country, and how and to what degree the state bodies will exercise control over the legality and suitability of the measures taken within the framework of the local selfgovernment bodies (Zagorc, 2008b: 13).

Regarding the issue of the incompatibility of the local-level functions - referring to the municipal council members (see also Zagorc, 2008a: 297-301), mayors and other officials in the local community - with the functions in the state bodies, several constitutional principles need to be followed: the principle of separation of powers within the framework of which the independence of the legislative, executive and judicial branches of government is emphasized, then the power decentralisation principle on which independence and autonomy of local selfgovernment is based, and finally the representative democracy principle that emphasizes the commitment of the people's representatives to the sovereign right holder, i.e., to the people themselves. All the principles require the establishment of an efficient system of checks and balances between the holders of various government functions. ${ }^{2}$

In foreign systems there is no established approach to the incompatibility of the functions at the state and local levels because the solutions of individual states differ considerably among themselves. In addition to the said constitutional postulates, the variety of solutions also depend on objective factors, such as tradition in an individual country, the actual power and independence of local communities in negotiating with the state, etc. One of the rare attempts of a 
broader regulation of the incompatibility of the function at both levels of government is the European Charter of Local Self-Government. In the third paragraph of Article 7, it only determines that any functions and activities which are deemed incompatible with the holding of local elective office shall be determined by statute or fundamental legal principles. ${ }^{3}$ The purpose of the provision manifests itself in two aspects. It first means that the incompatibility of the function may result from general legal principles, such as autonomy of local self-government, the principle of separation of powers, the principle of the representative mandate through which the rigidity of statutory regulation of the incompatibility of the function can be overcome. The other aspect reflects in providing a uniform regulation of the personal position of the local community officials irrespective of their territorial affiliation to a local community. The position of officials with equal competences in any local community should be equally regulated for all of them due to the uniform statutory regulation. Besides that the local communities are, in principle, prevented to determine by themselves the extent of the incompatible functions for their officials; in particular, they cannot narrow the list of incompatible functions, whereas the extension of the list should be restricted as much as possible. The Council of Europe also determined that incompatibility is justified only in the case of simultaneous performance of executive functions in the local community and in the supervisory state autorities and also in case where, within one function, the competences which have a decisive impact on the rights and legal interests of the local community are executed. Therefore, in the opinion of the Council of Europe, it is not desirable to perform more than two functions at different levels of the local self-government, and to perform not more than one executive function. It means that the Council of Europe does not object the performance of multiple functions at the same time whereat it gives greater attention to limitations of performing executive functions. It is obvious that the Council of Europe has determined only minimum standards for the incompatibility of the function which the democratic countries should exceed to an extent as large as possible. ${ }^{4}$

France is the best known country in which performance of parliamentary and mayoral functions is permitted under certain conditions. It may be defined as, so called, limited or conditional incompatibility of the parliamentary function with other functions. Unlike the standard two-sided form of incompatibility of the function with other function, it is a characteristic of the said incompatibility of the function that, in principle, certain functions are compatible with each other. And only then if a certain person already performs two compatible functions, the provisions governing the incompatibility of the function take effect. Thus, this person is not allowed to perform one more function (i.e., the third function) in addition to the said two functions. It is about an exceptionally rare provision that is a peculiarity of the French parliamentarism. The first paragraph of Article 141 of the Electoral Act provides that the National Assembly member's mandate is incompatible with performing more than one mandate or one of the following functions: a regional councillor, a councillor of the Corsican Assembly, a general 
councillor, a Paris councillor, a municipal councillor in the municipality in which there are fewer than 3500 inhabitants. It is on the basis of this provision that, in principle, a National Assembly member can perform one of the said functions or mandates in addition to the parliamentary mandate. In the two-sided relationship between the parliamentary function and other functions there is no incompatibility relationship. Therefore, in principle, a National Assembly member can perform also the function of mayor. At the moment when the relationship between the functions and mandates is broadened from a bilateral to trilateral relationship, the legal consequences are changed radically because the National Assembly member cannot perform the third function at the same time. Such a legal status is called a limited incompatibility of the function because the two functions are not incompatible in all cases (in French, it is called incompatibilité limitée) (Avril, Gicquel, 2004: 39). But on the other hand, this kind of relationship can be defined as the conditional incompatibility of the function because it will take effect only if a National Assembly member already performs one more function and also wants to perform the third function. However, the French regulation must not be seen as an example that can be uncritically transferred to other countries, particularly due the fact that the rules for electing a mayor are different in France.

In principle, the basic position holds good that the functions at the state and local levels differ by purpose and objectives, and that they cannot be performed at the same time. The ratio between performing the functions at the state and local levels is beautifully described by the statement that self-government in itself requires the incompatibility of the function (Leisner, 1967: 35). Leisner believes that municipalities as such cannot be represented through their representatives in the representative body of the state. The conflict of interest would be too explicit. The Constitutional Court of Slovenia which gives great significance to the conflict of interest avoidance in defining incompatible functions at the local and state levels has confirmed the legislator's decision that the regulation of the incompatibility of the function between the tasks and functions at the state level and the functions at the local level is not unconstitutional. Otherwise, the conflict of interest might occur during the performance of the tasks at the state and local levels. In the case that referred to the issue of the incompatibility of the functions at the local level with carrying out work in state bodies, the Constitutional Court said that

... the provision of the third paragraph of Article $37 \mathrm{~b}$ of the Local SelfGovernment Act is based on Art. 144 of the Constitution, which provides that State bodies supervise the legality of the activities of local community bodies, and on Art. 140, Para. 3 of the Constitution, providing that in matters vested in local community bodies by the State, State organs supervise the suitability and proper execution of their work.. The implementation of the said constitutional provisions requires that control be exercised impartially and independently. One of the conditions for exercising independent and impartial control over the local community bodies is undoubtedly the control exercised by the person who does not simultaneously perform any function in municipal bodies. The 
contested part of the provision determines absolutely clearly that incompatibility refers only to the workplaces at which employees exercise the described control and not to all the civil servants in the state administration. ${ }^{5}$

The Constitutional Court highlighted the state authorities' supervisory competences over the work of the local self-government bodies as one of the generators of the conflict of interests because of which the legislator should always prohibit the simultaneous performance of the executive tasks at the local level and the state's supervisory tasks if there is such a conflict of interests. It is about the execution of the principle that supervision is ineffective if a person supervises himself or herself.

\section{The Incompatibility of the Parliamentary and Mayoral Functions}

The institute of the incompatibility of the function is justified only in the cases when the prohibiting legal norm contributes to the protection of certain constitutional or legal principles whereat the existence and the extent of the incompatibility of the parliamentary and mayoral functions are to a large extent influenced by the mode of electing the mayor, the mayor's powers and by the reasons for his premature dismissal.

There are direct and indirect elections for electing the mayor. In some countries, an executive body is appointed by a certain state authority (for example, mayors are appointed by the King in Belgium) or there is a kind of the assembly system according to which the executive body derives from the representative body of the local community. In mayoral elections, indirect elections were traditionally more prevalent than direct elections. However, direct elections have been more and more widely applied lately, especially in former socialist republics. Indirect elections are currently applied in 11 countries: in the Czech Republic, Denmark, Estonia, Finland, France, Iceland, Latvia, Lithuania, Norway, Sweden, and, as a rule, also in Spain. The advantage of the indirect elections lies in the fact that they connect the mayor closer to the municipal council thereby strengthening the cohesiveness of local self-government as a whole. Indirect mayoral elections are held in municipal councils that elect the mayor by a majority vote. If the mayor is elected directly, both a relative majority system and an absolute majority system can be used in elections (Grad, Nerad, Zagorc, 2004: 470). To the greatest extent possible, the Slovene regulation takes into account the democratic principles because mayors are elected directly. In the Constitution, local self-government is regulated only at the level of a principle. It does not determine anything relating to the internal organisation of the local self-government units, and it leaves the actual regulation of the subject matter to the legislator. In its Article 42 the Local SelfGovernment Act (LSGA) determines that the mayor is elected by voters (who have permanent residence in the municipality) in direct, secret elections. ${ }^{6}$ The term of office of the mayor shall be for four years. In the event of early termination of office, the provisions of Article 37a of the LSGA shall be applied. 
These provisions define the cases of early termination of the municipal council member's term of office. It is provided for the mayor in Article 37 of the LSGA that the his mandate shall terminate in the following events: upon the loss of the right to vote, permanent inability to perform the function, a final judgment to have committed a criminal offence and with an imposed unconditional prison sentence of more than six months on him or her, and upon the mayor's resignation. In addition to the stated cases, the LSGA non-transparently regulates the issue of the incompatibility of the mayor's function, which is also one of the reasons for early termination of office. There is a general rule that the mayor's function is incompatible with other functions and work within the framework of the local community, namely, it is incompatible with the municipal council member and deputy mayor functions, with the Supervisory Board membership, with the work in municipal government, and with other functions for which the Act so determines. The LSGA does not regulate explicitly the incompatibility of the mayor's function with the functions at the state level.

The mayor's powers also have a significant impact on the incompatibility of the function. The mayor in a Slovene municipality performs several different competences that give him or her the role of the main performer of laws and municipal by-laws. The mayor is also given the role of the main proposer of municipal by-laws to be submitted for approval. His role includes the performance of executive, representative, initiative, coordinative and supervisory tasks in the municipality. The mayor represents the municipality and the municipal council, convenes it and chairs the sessions of the municipal council. However, he has no right of voting. Furthermore, he proposes a budget and the annual financial statement of the municipal budget for approval by the municipal council; he proposes ordinances and other acts from the municipal council competence, and takes care of the execution of the municipal council decisions. The mayor makes sure that the municipal charter, ordinances and other general municipal acts are published. The mayor has some other competences (Article 33 of the LSGA).

The mayor's term of office lasts for four years as in the case of the municipal council. However, early termination of his term of office is also possible. By way of exception, the mayor can be dismissed from his office if he neither implements the decisions of the Constitutional Court nor does he execute the final decisions of the court competent to decide on administrative disputes. These decisions impose on him the conduct in accordance with the Constitution and law. The procedure for the dismissal of the mayor is very complicated and subject to many substantive considerations and procedural safeguards primarily due to the protection of the local self-government autonomy in order to protect the local community from the unjustified interventions of the state bodies. Upon the Government's proposal, the National Assembly decides on the dismissal of the mayor, which results in the fact that only the body with the highest level of legitimacy may intervene in the existence of the governmental structures at the local level. Prior to issuing the decision on the dismissal of the mayor, the National Assembly must warn the 
mayor about his unlawful conduct thereby suggesting to him how he should eliminate these illegalities in due time. If the mayor acts in accordance with the warning, the National Assembly stops the procedure for dismissal from office by issuing a decision. The National Assembly dismisses the mayor if it ascertains that the reasons have not been eliminated, that all lenient legal measures have been taken, and that the dismissal of the mayor is an urgent measure in the given case to ensure local self-government in the municipality. The constitutional-court protection of the rights of the officials in local communities is possible against the decision of the National Assembly. Within 30 days after the receipt of the decision, the mayor can file a request for the constitutional review of the decision of the National Assembly. If the request has not been filed in due time or if it has not been granted, the mayor shall be dismissed on the day of the announcement of the decision of the National Assembly or Constitutional Court (Article 90b and Article 90c of the LSGA shall apply mutatis mutandis).

The incompatibility of the function of a National Assembly member is pettily regulated in the Constitution. But the incompatibility of the function of all the officials at the local level is entirely left to the legislator (see Zagorc, 2008a: 233238). This means that also the incompatibility of the simultaneous performance of parliamentary and mayoral duties is within the domain of the legislator. The issue of the simultaneous performance of the multiple elected functions and mutual incompatibility of the public functions, if it is about the functions of an Assembly member and mayor, was launched each time when the National Assembly discussed the law amending the Local Self-Government Act. The very incompatibility of the parliamentary and mayoral duties has been most problematic for a long time. No wonder that several very critical thoughts have been written regarding the option that the persons who perform parliamentary functions also perform the functions of the mayor in the local community (Lavtar, 2004: 16-17; Veljković, 2005: 125-135; Senčur, 2003: 6-7). Critical reflections result from experience of parliamentary practice and from the theoretical problems caused by the simultaneous performance of parliamentary and mayoral duties. In the foreign parliamentary practice, it has turned out that the mayor's work in the parliament is curtailed and that the mayor's duties are frequently the reason for the mayor's non-attendance at parliamentary sittings and at working body sessions. The other problem lies in the fact that instead of putting emphasis on the legislative branch that has no proper control over the work of the executive branch of government, the mayors themselves perform some kind of executive function within their local community (Depauw, Thomas, 2000: 79).

An interesting aspect of the Slovene regulation is that it cannot be clearly said whether or not the incompatibility of the function applies to the parliamentary and mayoral functions. The Act states that a member of the National Assembly must not professionally perform any functions in the local community authorities (Article 10 of the National Assembly Members Act). ${ }^{7}$ The purpose of the legislator is to somehow disable the Assembly members to perform the functions 
at the local level whereat the issue of the professional or non-professional performance of the functions at the local level is partially left to the Act, partially to the municipal charter and currently even to the municipal officials. In principle, it holds good that municipal officials perform their functions on a nonprofessional basis whereat the mayor may decide to perform his functions on a professional basis. It is about the autonomous decision taken by the mayor (the first and second paragraphs of Article 34a of the LSGA). Prior to the currently applicable regulation, the manner of performing the mayor's duties was determined by the municipal charter according to which the municipal council was not obliged to determine or not to determine the incompatibility of the function. The Constitutional Court has already decided on this issue. In one of its decisions, it explained the matter as follows:

Since the Mayor was elected a National Assembly member, the Municipal Council does not have to change the statutory provisions governing the performance of the Mayor's duties on a professional basis. Subject to the provision of Article 10 of the NAMA, the Assembly member function is incompatible with the Mayor's function if the latter is performed on the professional basis. The fact that the Mayor was elected a National Assembly member does not influence the legality of the statutory provision according to which the Mayor performs his function on a professional basis. The Act determines in Article 11 that the Assembly member function (and not only the employment relationship) terminates on the day the mandate was approved. The second paragraph of Article 37a of the LSA explicitly speaks about the termination of the mandate and not only about the termination of the employment relationship. It is obviously unjustified to maintain that the municipal charter would have to enable the Mayor to perform his functions on a non-professional basis if he has been elected a National Assembly member as a Mayor who performs his functions on a professional basis. ${ }^{8}$

It is obvious that it was about a completely autonomous regulation of the Mayor's status by the municipality and that it was not subject to the control of the state bodies. This means that such a regulation was undoubtedly contrary to the guidelines that result from the ECLSG. The regulation of the incompatibility between the two functions at the state and local levels should be governed by law and not by implementing regulations or even by the decisions taken by an individual. The law should prevent both the Government intervention and autonomous regulation based on the statutory rules of the municipality or municipal officials. The Slovene regulation of the local self-government enabled the municipality to determine the incompatibility by itself, i.e., not directly, but with entirely equal effects as if the legislator determined the incompatibility of the mayoral and parliamentary functions. Such an approach of the legislator which gives the municipalities an option of political arbitration regarding the incompatibility of the function needs to be criticised. Firstly, the legislation permits unequal treatment of mayors. In some municipalities, the mayors are 
allowed to be the National Assembly members. In other municipalities, they are not allowed. Since the mayors are by law equal in the term of office, election mode, the mayor's powers and the termination of the mayor's term of office, it is quite understandable that the legislator leaves the decision on the incompatibility of the functions to the officials themselves. So, without any reasonable reason, the Act favours the mayors who perform their functions on a non-professional basis as compared to those who perform them on a professional basis. If the Act incapacitates professional mayors from performing parliamentary functions, it is supposed to incapacitate also non-professional mayors from performing them. That is to say, both of them have the same scope of competences and duties within the framework of the local communities. The LSGA distinguishes between the functions, performed on a professional and non-professional basis, only regarding determining the personal income or personal income compensation, and not regarding other matters. The Act defined the performance of the mayor's functions on a non-professional basis because it wanted to encourage the persons who are successful and reputable in the local environment to participate in the governance of public matters. And the Act did not in any way enable such a mayor to perform also the parliamentary functions. That is why, contrary to the principle of equality, the Act gives preference to non-professional mayors in comparison with the professional ones. The currently applicable regulation provides that the mayor may independently decide to perform the function on a professional basis (the second paragraph of Article $34 \mathrm{a}$ of the LSA). Such a solution is even worse than the previous one because it permits arbitrary and non-uniform application of the provisions governing the incompatibility of the functions of mayors.

In addition to the already mentioned reproaches against the Slovene legislation, it is appropriate to present some more legal and theoretical thoughts that point to the constitutional suspectness of permitting simultaneous performance of mayoral functions on a non-professional basis and parliamentary functions. The parliamentary function can be simultaneously performed only by the nonprofessional mayors who have decided to perform their functions of the mayor on a non-professional basis. The Act only determines that the Assembly member must not perform any function in the local community bodies (Article 10 of the NAMA) on a professional basis [emphasized by S.Z.]. Although some authors mention that the main reason for the incompatibility of the indicated functions is consistent implementation of the principle of separation of powers, the reasons for the incompatibility of the function have their basis in other provisions of the Constitution. These authors say that the principle of separation of powers requires an exact division of the competences between the legislative and executive branches of government, i.e., their functional independence. There is no doubt that local communities serve as a part of executive authorities because they, likewise the Government and the direct state administration, execute not only local (own) regulations, but also the acts and state regulations. They are part of the public administration system which, in parallel with the state administration, performs a significant part of administrative tasks. These tasks have a basis in law and in 
other decisions of the National Assembly. Thus, in the case of the simultaneous performance of the mayoral and parliamentary functions, we have come to the absurd situation where the mayors in the role of the Assembly members lay down the rules for themselves how they are going to act because the basic powers and tasks of the local authorities are prescribed by the Constitution and law (Senčur, 2003: 6-7). The Constitution provides only institutional protection of local selfgovernment thereby leaving most matters to the autonomy of local communities. Therefore, the Slovene regulation might be defined similarly as in the German theory that the vertical division of power between the state and local communities implies no automatic incompatibility of functions as this is the case for the horizontal division of power at the state and local levels (Achterberg, Schulte, 2000: 1246). This implies that the incompatibility of the function should be explicitly and unambiguously prescribed because it must not be presumed on the basis of general constitutional principles about the vertical division of powers or the autonomy of local self-government.

The next reason for criticism derives from the constitutionally determined representative mandate of the Assembly members according to which they should represent the interests of all citizens (the first paragraph of Article 82 of the Constitution). A similar issue was raised in the German theory (Schefold, 1997: 13-15). Observance of this basic principle of the representative democracy is largely at risk if an Assembly member is also a mayor because the latter is obliged to represent also the interests of his municipality (the first paragraph of Article 33 of the LSA). An Assembly member who is also a mayor participates in adopting the legislation that refers to the operation of the local self-government. This is the legislation he as a mayor, is obliged to implement. This means that he is going to make decisions in adopting legislation not only as a representative of the people, but also as the future executor of these regulations. The functions of an Assembly member who is also a mayor are already a priori in a conflict of different interests (Senčur, 2003: 7).

The dual mandate of an Assembly member, who is also a mayor, can be questionable in the light of the enforcement of political responsibility by voters, and in the light of ensuring the principle of equality in all the local community units. The Assembly member who is also a mayor has been directly elected twice. He executes two mandates at the same time: the mayoral and parliamentary mandate. This duality of roles can be questionable in the light of the transparent operation of the state bodies because it is not possible to distinguish the parliamentary activities (of the Assembly member who is also a mayor) from the mayoral tasks. The voters therefore do not know to which group of the competences the activities of the Assembly member, who is also a mayor, fit to, and how to evaluate the conduct of the dual-mandate official. Another reproach against the dual-mandate officials derives from the fact that the municipalities and their inhabitants, whose mayors are also Assembly members, are in a better position than other municipalities. In their work, such Assembly members are 
going to largely take into account, knowingly or unknowingly, the interests of the municipalities whose officials they are. By doing so, they are going to put the inhabitants of all those municipalities, from which no Assembly member comes, to a worse situation. Both reproaches are predominantly of a political nature and they merely reflect an abstract or potential conflict of interests at work of dualmandate officials (Zagorc, 2008b: 18-19).

In the countries where public expenditure is extremely high, Slovenia is one of them, adopting a budget might represent an important aspect of possible financial conflicts of interest due to the duality of the functions of a mayor and an Assembly member. In the national budget, certain financial resources are provided for the local communities as budget users along with the foreseen expenditures for individual purposes of local communities. The balanced budget, the principle of equality or equality between local communities (e.g., in determining the extent of entitlements to local communities) and the security of tenure of local communities as budget users are, due to inconsistently delimited powers between the legislative and executive branches of government, in a constant probation. The budget can be an important element of economic policy and the balanced regional development policy (and local development in its framework) which is in a general interest of the society and in the interest of the less-developed regions. However, it can become one of the main brakes of development due to the very compatibilities of the functions (Senčur, 2003: 7).

\subsection{Criticism of a Triple Mandate by Way of Illustration of the Deputy Mayor's Functions}

In Slovenia, the function and position of deputy mayors partially differ from the mayor's, although the two functions are closely interconnected. Obvious differences manifest themselves primarily in appointing the deputy mayor, in early termination of office, and in the deputy mayor's powers themselves. The legislation determines that each municipality must have at least one deputy mayor or several of them. Only the person who has been elected into the municipal council can be appointed deputy mayor. The mayor appoints him or her at his own discretion and can dismiss him any time. The deputy mayor represents an additional link between the mayor's office and the municipal council because the deputy mayor is also a member of the municipal council, whereas the mayor must not sit in it. Upon the mayor's powers of presentation and chairing the municipal council, close connectivity and even personal intertwining of both bodies manifest themselves in the very position of the deputy mayor. It is interesting to note that the mayor is not a member of the municipal council, and therefore he has no right to vote, whereas the deputy mayor may vote. With regard to the connectivity of the roles of the mayor and deputy mayor, strategically viewed, the mayor has his 'prolonged hand' in the municipal council (Zagorc, 2008b: 20). The deputy mayor's powers cannot exceed those of the mayor, and they entirely depend, similarly as the deputy mayor's mandate, on the mayor's decisions and position. 
The deputy mayor performs the tasks of substituting the mayor in the case of the early termination of office, or in the absence of the mayor. The deputy mayor's task is to help the mayor with his work and to perform individual tasks within the mayor's powers on the basis of a special authorisation issued by the mayor.

By way of exception, the deputy mayor may perform two more functions at the same time, which ranks him among the most heavily burdened officials in Slovenia. As a deputy mayor, he has to be a member of the municipal council that is directly elected by the voters in the municipality. He may also perform the function of the Assembly member if he has been elected in the direct parliamentary elections. The permissible condition for simultaneous performing of all the three functions is that the deputy mayor did not request for the approval of performing the function on the professional basis, or he obtained no such approval of the mayor. Although it is about a very rare example with a triple mandate where the allusion to the well known "Concrete Criticism of the Official with a TripleMandate" (Novak, 2005) is not accidental, certain issues of the incompatibility of the Assembly member's function with the deputy mayor's function differ as compared to the mayor's function. Despite the three functions, the financial conflict of interest is expressed in the same way as in the case of mayors because the deputy mayor receives no attendance fee, no special compensation fee, and no award for participating in municipal council meetings. The problem of the triple mandate can lie in excessive powers of the deputy mayor in exceptional cases, especially when he substitutes the mayor and simultaneously performs the tasks of the municipal council member. Thus, undoing the municipal council's control over the deputy mayor's work becomes more evident. Three persons were performing the tasks of the deputy mayors and Assembly members during the National Assembly's mandate period from 2004 to 2008.

\section{Conclusion}

An important aspect of the incompatibility of the function, which was not particularly highlighted in the paper, but it deserves mentioning, is in the fact that individuals should be aware that performing the multiple functions, obtained in elections, is not a privilege, but it is a commitment and duty to perform the functions well and with dedication. It could be said that the institute of the incompatibility of the Assembly member's function represents a kind of a mirror of what an Assembly member is supposed to be like. The incompatibility of the function imposes a variety of does and don'ts on the Assembly member. Through the relationships to other functions, to profitable and non-profitable activities, the Assembly member shapes his or her parliamentary status. Ideally viewed, the Assembly member's duties should be performed by an individual who would be able to ignore his / her own volitions, wishes and interests, to pay full attention to implementing the mandate obtained in the election, and to aim at implementing the public interest. If such an ideal Assembly member exists at all is the question worth giving a thought over. However, it can be ascertained that an ideal 
Assembly member needs no special government regulations telling him what he may and what he may not do during the Assembly member's mandate period because he would find the decency limit and ethical conduct in himself and not in regulations (Zagorc, 2008a: 382). The same also applies to the elected mayors and appointed deputy mayors.

Although the professional public are more or less uniform in evaluating the dual mandate of an Assembly member who is also a mayor, we cannot, on the other side, avoid the conclusion that the discussed dual- or even triple-mandate officials are neither unconstitutional nor unlawful in themselves, although it is about incompatibility of the interest roles played simultaneously by these dual- or triplemandate officials. Despite the fact that the issues of such regulation have been more than obvious, it seems that among the political parties, represented in the National Assembly, especially among the ruling coalition parties, there is no true political will for more consistent implementation of the principle of separation of powers, which would contribute to limiting party democracy and to strengthening the country's democracy (Senčur, 2003: 7).

\section{Notes}

${ }^{1}$ Cf. the Decision of the German Federal Constitutional Court, BVerfGE 58, 177, 193.

2 Similarly, but not quite in an overall way, it is written in the explanation of the Local SelfGovernment Bill, EVA: 2003-1711-0088, dated 27.11.2003.

${ }^{3}$ European Charter of Local Self-Government, ETS, No. 122, dated 15.10.1985, hereinafter referred to as ELLS.

${ }^{4}$ Inferred from the explanation of the Local Self-Government Bill (ZLS-1), first reading, Poročevalec DZ, No. 107/2003.

${ }^{5}$ Decision of the Constitutional Court RS U-I-39/95, of 23.9.1998 (OJ RS, No. 68/98).

${ }^{6}$ Local Self-Government Act, officially consolidated text, OJ RS, No. 94/2007, hereinafter referred to as LSGA.

7 The National Assembly Members Act, officially consolidated text (ZPos-UPB2), OJ RS, No. $112 / 2005$, hereinafter referred to as NAMA.

8 The Constitutional Court Decision, RS, U-I-44/97, dated 27.2.1997.

\section{References}

Achterberg, N. \& Schulte, M. (2000) komentar k 38. členu nemške ustave, v: Starck, C. (ur.) \& von Mangoldt, H. (ur.) \& Klein, F. (ur.) Das Bonner Grundgesetæ: Kommentar (München: F. Vahlen).

Avril, P. \& Gicquel, J. (2004) Droit parlamentaire (Pariz: Montchrestien).

Depauw, S. \& Thomas, I. (2000) »Prologues Without a Play?« A Quantative Approach to the Significance of the Belgian Individual Parliament Member, v: Longley, L. D. (ur.) \& Zajc, D. (ur.) \& Ágh, A. (ur.), Parliamentary members and leaders: the delicate balance (Appleton: Lawrence University).

Foucault, M. (2006) How Useful is the Cumul des Mandats for Being Re-elected? Empirical Evidence from the 1997 French Legislative Elections, French Politics 4, 292-311. 
Grad, F. \& Nerad, S. \& Zagorc, S. (2004) Volilni sistem Republike Slovenije za lokalne volitve, v: Lavtar, R. (ur.) Dokumenti in studije o pokrajinah v Sloveniji 2000-2004 (Ljubljana: MNZ RS).

Lavtar, R. (2004) Medsebojna nezdružljivost župana in poslanca, Pravna praksa, 23(42), pp. 1617.

Leisner, W. (1967), Die Unvereinbarkeit von öffentlichem Amt (Wiesbaden: Deutsche Fachschriften). Novak, B. (2005) Pavlihova frača, IV. del (Ljubljana: Revija SRP).

Schefold, D. (1997) Kommunalwitschaftliche Inkompatibilität (Stuttgart: Verlag W. Kohlhammer). Senčur, M. (2003) (Ne)združljivost županske in poslanske funkcije, Pravna praksa, 22(35), pp. 67.

Veljković, B. (2005) (Ne)združljivost funkcij in javno mnenje, Javna uprava, 41(1), pp. 125-135.

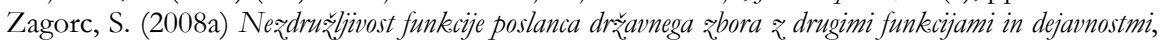
doktorska disertacija (Ljubljana: Pravna fakulteta Univerze v Ljubljani).

Zagorc, S. (2008b) Nezdružljivost poslanske funkcije s funkcijama župana in podžupana REVUS, 7, pp. 11-22. 